\title{
Public Service Transformation (A Case Study of Online Single Submission at The Office of Investment and Integrated Services Magelang Municipality)
}

\author{
Angga Dwi Saputra, Arif Budy Pratama, Eny Boedi Orbawati \\ Science of State Administration, Tidar University \\ Email: ${ }^{1}$ anggadwisaa@gmail.com, ${ }^{2}$ arifpratama@ untidar.ac.id, \\ 3enyorbawati@yahoo.co.id,
}

(Received: May 1-2019; revised: May 9-2019; published: May 31-2019)

\begin{abstract}
This study aims to analyse public service transformation from One Stop Integrated Service (PTSP) to Online Single Submission (OSS) model. The study was conducted at The Office of Investment and Integrated Services (DPMPTSP) Magelang Municipality. Using case study as a research strategy, the data was collected from in-depth interviews and documentation. The data were analysed using taxonomic analysis techniques. The results show some changes in several dimensions of services such as data input, service focus, issuing business licenses process, service systems and the time needed in the licensing service process. From the functional-structural theory perspective, service transformation from PTSP to Online Single Submission at The Office of Investment and Integrated Services Magelang Municipality underwent due to regulations from the central government with the aim of accelerating and facilitating business services. However, the licensing application system integration has not been running well due to application system transition. Thus, the service transformation process from manual to online should pay attention to the integration of the old system into the new one.
\end{abstract}

Keywords: Transformation; Services; Online Single Submission.

\section{INTRODUCTION}

Public services according to Sinambela (2008) is any activity undertaken by the government to serve human needs and offer satisfaction to the citizens. This service activity is organized by the government, both the central government, provincial and regency/municipality according to the level and type of services respectively. This mechanism is regarded as multilevel governance system in public service delivery. According to Worldwide Governance Indicators (2018) on Government Effectiveness, Indonesia's ranking is still under Southeast Asian countries such as Singapore, Malaysia, and Thailand. Indonesia has a total of 54.81 points, while Singapore 100, Malaysia 76.44, and Thailand 66.83. This ranking shows that public service conditions in Indonesia still need to be improved.

The government is obliged to build community confidence through the implementation of good public services along with the expectations and demands of society included in the licensing service (Andayani, 2016). According to the Ombudsman data RI (2018) on compliance with public service standards, assessment of the fulfillment of standard components of service in 85 city government (government) indicates that as many as $15 \%$ or 8 government in red zone with predicate for low compliance, $56 \%$ or 31 government in yellow zones with 
78| Jurnal Ilmiah Ilmu Administrasi Publik: Jurnal Pemikiran dan Penelitian Administrasi Publik
Volume 9 Number 1, January - June 2019. Page 77-86

moderate compliance predicate, and $29 \%$ or 16 government in green zone with high compliance predicate. The waiver of this standard of public service will encourage potential maladministration behaviour and corrective behaviour. In the long run, such neglect may result in declining government credibility.

Amid public complaints about public services, the government issued a Government Regulation number 24 year 2018 on the Electronic Integrated Business License Service. Product of this regulation is the Online Single Submission Service System. This system is different from PTSP that has been launched by the previous government. During this time PTSP still experience number of weaknesses. One of the most obvious is duplication in license process both in local government and national/central authority. While in the Online Single Submission service system, all licensing starts from the central level to the region into a single unity and mutual support.

Online Single Submission has some advantages. Firstly, there is a task force (Satgas) that controls the course of the licensing process from start to finish. Secondly, information technology plays an important role by providing more modern and fast registration model. Thirdly, the data that has been registered can be used to apply other licensing, so that investors do not have to bother to reregister within the system.

Magelang Municipality is a city that was able to reach the first rank of the Regional Competitiveness Index (IDSD) of Central Java in 2018. Magelang has also been implementing Online Single Submission Services in The Office of Investment and Integrated Services. To be able to access this service, the community does not have to come to the office so it can save time and money.

Study on online-based public services has been widely done in Indonesia. Some studies on online-based public services focusing their study on effectiveness of service (Arisandi, 2013; Marlina, 2017), the process of digitizing public service (Sufi \& Herlinda, 2017; Ulfa \& Sulfiani, 2018), service results (Hasoloan, 2017). However, the study on transformation and its properties is still rare. This study aims to contribute the academic debate on this topic.

The concept of public service has shifted from product based approach to service based approach. Please note, product based approach is a service based on the product where people make bridges, make market, products are there. Meanwhile, service based approach is to place the user as the main factor in public service. Osborne, Radnor, \& Nasi (2013) in that case revealed that the product-based service has a weakness because it refers to the management of services for private. Meanwhile, the study of Aschhoff \& Vogel (2019) states that public professionals are increasingly engaged in collaborative relationships with citizens to design, implement, and evaluate public services.

Transformation in the context of public policy according to Rothwell (2015) is one of the attempts to find breakthrough results. Other opinions expressed Lederer, Wallbott, \& Bauer (2018), more transformation aimed at reconfiguring the structure, process, and constellation of actors, thus potentially challenging policies (institutions), policies (content), and also politics (processes) of certain systems. Based on these definitions, it can be concluded that the transformation is a displacement of a condition to another condition that causes changes to a particular object. 
Referring to the various descriptions above, the authors concluded that the transformation of public service is a displacement of a condition to other conditions that cause changes to the fulfillment of community needs provided by the public service provider.

Transformation of public service from manual to online can be viewed as a social system. According to Talcott Parsons, the social system must have a balance or equilibrium between the parts contained therein. The basic concept of Parsons regarding social systems is the stabilization and harmonious regularity. Thus, the slightest change in any of the subsystems will be followed by the change of other elements until the change in the system as a whole. In this study, authors formulate two research questions. First, what have been changed in the transformation process from One Stop Integrated Service (PTSP) to Online Single Submission (OSS) in The Office of Investment and Integrated Services Magelang Municipality. Second, how can we explain the process of transformation using structural-functional theory.

\section{METHOD}

A qualitative approach with a case study as a research strategy was conducted to tackle the research questions. Qualitative study is intended to explore and understand the meaning by which a number of individuals or groups of people are considered to be derived from social problems (Creswell, 2013). This study was conducted in The Office of Investment and Integrated Services (DPMPTSP) in Magelang Municipality. Data collection techniques are conducted with interviews and documentation. While the determination of informant using purposive sampling and snowball sampling. The data was derived from data and information management, online operator supervisor, technical team head, online service operator, and manual service staff. To analyse the data, authors occupied taxonomy analysis techniques.

\section{RESULT AND DISCUSSION}

Changes in the licensing services in The Office of Investment and Integrated Services Magelang Municipality occurred due to government issued Government Regulation number 24 year 2018 on the Electronic Integrated Business License Service. The changes occurred in 5 dimensions of service.

\section{Data Input}

Service changes occur in the licensing data input process. In the PTSP service, business actors must come to The Office of Investment and Integrated Services Magelang Municipality to obtain licensing services. The service Staff in the office will input the data in accordance with the requirement files carried by the business actors. After the issuance of the Online Single Submission service system, the business actors input the data directly through the OSS website. Business actors can access this service at any time wherever they are. They do not have to come to the office.

\section{Focus Services}

The focus of PTSP services initially provides the services thoroughly to the business actors. The services range from registration, file verification requirements, data input, survey 
80| Jurnal Ilmiah Ilmu Administrasi Publik: Jurnal Pemikiran dan Penelitian Administrasi Publik Volume 9 Number 1, January - June 2019. Page 77-86

process and business license issuance. Now the PTSP is no longer focused on the service, but it focuses more on monitoring the data that have been enter by business actors.

\section{Issuance of Business License}

PTSP service process is different with Online Single Submission. In PTSP service, the process of issuance of business license starts from the perpetrator of registration, completing the requirement file, verification of files by service staff, data input, and surveys. After the survey process is completed, the business actors can monitor the approval or absence of licensing. If approved, it is issued a business permit. If not approved then the requirement file will be returned to the business person through Front Office staff. Business permit issuance process through PTSP can be described as follows:

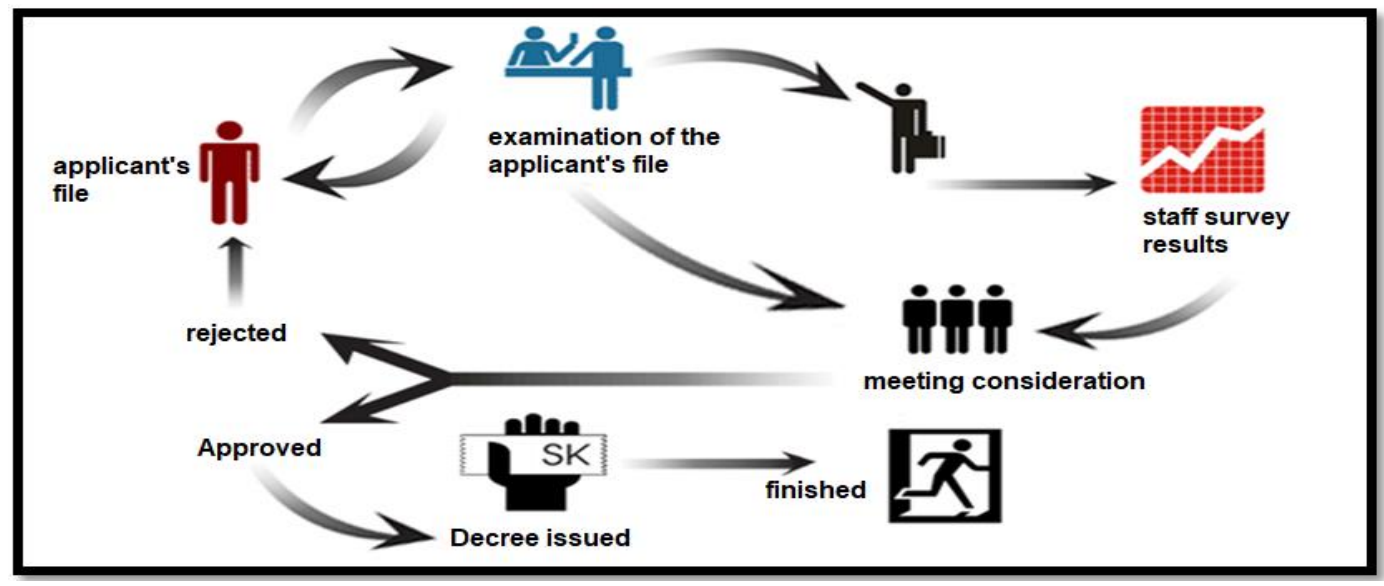

Source: (DPMPTSP at Magelang Municipality, 2019)

Picture 1. Process of PTSP service

In the Online Single Submission service, the business license issuance process originated from businesses inputting data to the OSS website. After that, business actors will be notified of a business license and commitment from the OSS system. In short, the business license through the OSS system is published first but with condition. While in the PTSP service, business licenses are issued in the last process after the survey process was approved. The business license issuance process through Online Single Submission can be described as follows:

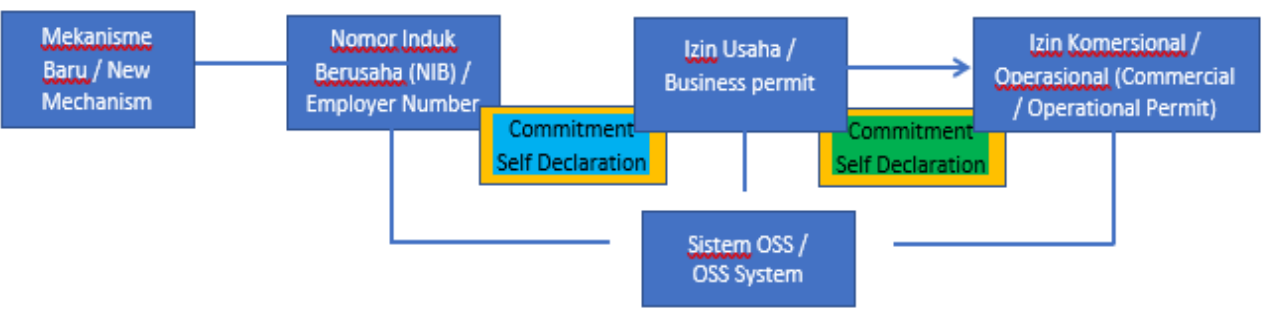

Source : (DPMPTSP at Magelang Municipality, 2019)

Picture 2. Process of Online Single Submission service 


\section{The System}

The service system through PTSP differs from the Online Single Submission system. Before the issuance of Government Regulation number 24 year 2018, The Office of Investment and Integrated Services Magelang Municipality still use manual system in the business process. After the issuance of the regulation, licensing services using online system which manage centrally by central government.

\section{Time}

The time it takes in the service process through PTSP is longer than Online Single Submission. In PTSP service, business actors take about 5 days to get SIUP (Trade business license). After the existence of Online Single Submission, Business actors only take 1 hour to get SIUP.

In short, the changes of licensing service at The Office of Investment and Integrated Services Magelang Municipality can be depicted in the following table:

Table 1. Changes in licensing services at DPMPTSP Magelang Municipality

\begin{tabular}{llll} 
No. & \multicolumn{1}{c}{ Dimensions } & \multicolumn{1}{c}{ Before } & \multicolumn{1}{c}{ After } \\
\hline 1. & Data Input & Staff & Investor \\
2. & Focus Services & Full service & Monitoring \\
3. & Issuance of Business License & In the End & In the Beginning \\
4. & The System & Manual & Online \\
5. & Duration & Day & Hour \\
\hline
\end{tabular}

\section{Transformation Process of Online Single Submission services at DPMPTSP Magelang Municipality}

Study on the transformation process of Online Single Submission services in The Office of Investment and Integrated Services Magelang Municipality uses four main aspects namely: 1) Adaptation, 2) Goal Attainment, 3) Integration, and 4) Latency. The study also examines how the challenges faced in the process of transformation.

\section{Adaptation}

The change of service from manual to online occurred because of Government Regulation number 24 year 2018 on the Electronic Integrated Business License Service. The government issued this regulation in order to accelerate and increase investment in Indonesia. Through the provision of Online Single Submission service system, business actors as well as investor can register and manage the issuance of business licenses, integrated commercial/operational permits. Through Online Single Submission, applicants of license is the main actor in this system.

Online Single Submission is a new service system. The process of transferring the service from manual to online can be seen in terms of applicants who have access directly. 


\author{
82 Jurnal Ilmiah Ilmu Administrasi Publik: Jurnal Pemikiran dan Penelitian Administrasi Publik \\ Volume 9 Number 1, January - June 2019. Page 77-86
}

Consequently PTSP is not focused on service but more focused on supervision. In addition, changes occur in the business license issuance process. In the PTSP service, business licenses are issued in the background after the survey process is approved. As for the Online Single Submission service, business licenses are issued first at the beginning of the service process but provided.

The licensing service at The Office of Investment and Integrated Services Magelang Municipality has adapted to the Government Regulation number 24 year 2018. The transfer of services from manual to online occurs due to intervention or regulation from the central government. This means that top-down properties of regulations that are established and set by the central government is applied at the lower level. Therefore, The Office of Investment and Integrated Services Magelang Municipality must adapt to adjust the regulation.

\title{
Goal Attainment
}

The Online Single Submission service system differs from PTSP. The time required to take care of licensing through PTSP is longer, can be up to days. As for the Online Single Submission service, permissions can be completed in just a matter of hours. This is because the Online Single Submission Service System is integrated electronically with various ministries or related agencies.

The Online Single Submission service at The Office of Investment and Integrated Services Magelang Municipality based on Government Regulation number 24 year 2018. Please be aware that the mindset of employees related to the purpose of organizing the Online Single Submission service because it follows the regulation to accelerate and facilitate the service.

\section{Integration}

DPMPTSP serves 79 licensing in Magelang Municipality. However, not all of these permissions go into the Online Single Submission service system. The licensing in Magelang that has not yet entered into the Online Single Submission system is still a lot, including the permit of pharmacy, permit to practice the doctor, permit midwives practice, and so on. To take care of licensing that has not yet entered into the Online Single Submission system, applicants must obtain the NIB (parent number attempted) first through the Online Single Submission system. Then, applicants must come to The Office of Investment and Integrated Services Magelang Municipality to obtain a commercial/operational permit by carrying a predefined file of requirements. After the commercial/operational permits are issued manually, service staff will upload the permission to the Online Single Submission system to obtain effective commercial/operational permits.

Service switching from manual to online requires intersystem integration. The central government provides 2 alternative options to integrate the old system into the Online Single Submission system. Each region is given the freedom to use applications that are already provided by the central Government or applications that have been made by each region. In that case, The Office of Investment and Integrated Services Magelang Municipality until now has not selected the application used to integrate the old system into the new system. This is because 
the integration process is not complete and the Online Single Submission system is still fixed. So, for a while this integration system used still use the old application.

\section{Latency}

The Online Single Submission service system is a regulatory product made by the central government. When the regulation has been issued, the local government automatically as a hand extension of the central government must comply and enforce such regulations. Sustainability of the Online Single Submission service in The Office of Investment and Integrated Services Magelang Municipality depends on the regulation made by the central government. This shows that the mindset of the Online Single Submission service follows the direction or regulation that has been set.

\section{Discussion}

Study on online-based public services conducted in various regions turned out to have similarities and differences with the results of this study. In previous studies for example Arisandi (2013), Sufi \& Herlinda (2017), and Hasoloan (2017) focus on online service. However, the service transformation was not explained from manual to online mechanism. In this study the authors explain the transformation process of Online Single Submission service in The Office of Investment and Integrated Services Magelang Municipality using structuralfunctional theory. In addition, the process of transformation has also been scrutinized.

The results of this study is in line with others such as Arisandi (2013) and Marlina (2017) who argue that of online public service is aimed to provide convenience for the citizens. The service users can access the permissions directly at any time wherever he is through the Online Single Submission system. The service users do not come again to The Office of Investment and Integrated Services Magelang Municipality to get licensing services. Citizens as service users can already access the Online Single Submission system. The service staff also still provide assistance desk to the public who have not been able to use the Online Single Submission system in order to take care of the licensing.

The result was also similar with previous study conducted by Hasoloan (2017). His study show that the system and operational procedures of ship service and online-based goods provide increased time efficiency, transparency, fairness, and balance and ease of service process. Equality with the results of this study lies in the efficiency of time and ease in the service process. Before the issuance of the Online Single Submission service System, the business actors took about 5 days to obtain a SIUP (trading business license). After the issuance of the Online Single Submission service System, business actors only take 1 hour. In addition, business actors can also access the Online Single Submission service directly at any time wherever he is, without having to come to the office.

Other results that differ from previous study are the challenges faced in the process of transforming the service from manual to online. Based on functional-structural theory, the challenge can be found in the adaptation aspect within the process of licensing service and application of Online Single Submission system. The challenge in the licensing service process is the lack of understanding of business participants about the Online Single Submission service 


\author{
84 Jurnal Ilmiah Ilmu Administrasi Publik: Jurnal Pemikiran dan Penelitian Administrasi Publik \\ Volume 9 Number 1, January - June 2019. Page 77-86
}

System. Errors in the data input process can harm the business person in obtaining licensing. Business actors need more time, cost, and energy to take care of the mistakes that occur in the process. This will have an impact on business licenses that do not immediately publish. While the challenge of service system applications is caused by Roll Back which means the difficulty of returning again to the initial process if there is mistake in the data input. The process for cancelling parent number attempting (NIB) must reach the relevant ministry. So, any process of data input on the Online Single Submission service system should be completely valid.

\title{
CONCLUSION
}

According to the description of changes in service dimensions in the transformation process Online Single Submission in The Office of Investment and Integrated Services Magelang Municipality, the authors conclude that there are changes in Online Single Submission namely data input, service focus, issuance of business license, service system and the required time in the licensing process. In the PTSP service, data input is done by the service staff. After the existence of the Online Single Submission service System, the input of data is done by the business actors. The focus of PTSP services that initially provide services thoroughly, now switches to the supervision of data entered by the business actors. Business licenses previously issued at the end, are now published at the beginning but on condition. The service system that was originally manual now changes to the online system. The time required in the service process through One Stop Integrated Service (PTSP) is about 5 days. After the issuance of the Online Single Submission service System, business actors only take 1 hour to take care of licensing.

The process of Transformation Online Single Submission service at The Office of Investment and Integrated Services Magelang Municipality is driven by top-down intervention especially Government Regulation number 24 year 2018. Therefore, DPMPTSP Magelang Municipality must adapt to adjust the regulation. It means the transformation of the service is not the will of the internal DPMPTSP Magelang Municipality, but top-down from the central government to the local government. The purpose of the Online Single Submission service is to follow the regulation in the form of accelerating and facilitating services. However, the previous applications system is still used by the DPMPTSP Magelang Municipality. Thus, it sometimes faces obstacles in the integration process. To tackle these issues, The Office of Investment and Integrated Services Magelang Municipality may consider to maintain the system integration and improve the application system.

\section{REFERENCES}

Andayani, S. (2016). Inovasi Pelayanan Publik (Studi Upaya Inovasi Paket Perizinan oleh Badan Pelayanan Perizinan Terpadu Kabupaten Sidoarjo dalam Meningkatkan Kualitas Pelayanan Perizinan). Jurnal Kebijakan dan Manajemen Publik, Vol. 4, No. 3, 1-9. 
Angga Dwi Saputra, Arif Budy Pratama, Eny Boedi Orbawati; Public Service Transformation... | 85

Arisandi, R. (2013). Penerapan System Online Payment Point (SOPP) Dalam Pembayaran Rekening Listrik di PT. POS (Persero) Cabang Kota Samarinda. eJurnal Ilmu Pemerintahan, Vol. 1, No. 2, 575-587.

Aschhoff, N., \& Vogel, R. (2019). Something old, something new, something borrowed: Explaining varieties of professionalism in citizen collaboration through identity theory. Public Administration. https://doi.org/10.1111/padm.12589.

Creswell, J. W. (2013). Research Design Pendekatan Kualitatif, Kuantitatif, dan Mixed Edisi Ketiga. Yogyakarta: Pustaka Pelajar.

DPMPTSP Kota Magelang. (2019). Retrieved Maret 22, 2019, from Portal Perizinan Online: http://dpmptsp.magelangkota.go.id/index.php/perizinan/portal

Hasoloan, A. (2017). Sistem dan Prosedur Operasional Pelayanan Kapal dan Barang Berbasis Online Pada PT. Pelabuhan Indonesia I (Persero) Cabang Pelabuhan Belawan. Jurnal Publik UNDHAR MEDAN, Vol. 3, No.2, 105-119.

Lederer, M., Wallbott, L., \& Bauer, S. (2018). Tracing sustainability transformations and drivers green economy approaches in the global south. Journal of Environment \& Development, 27(1), 3-25. https://doi.org/10.1177/1070496517747661.

Marlina. (2017). Efektivitas Sistem Perizinan Online dan Tracking Sistem (SPOTS) Pada Dinas Penanaman Modal dan Pelayanan Terpadu Satu Pintu (DPMPTSP) Kabupaten Siak. Jom FISIP, Vol. 4, No. 2, 1-10.

Ombudsman RI. (2018, Februari 2). Retrieved November 13, 2018, from http://www.ombudsman.go.id

Osborne, S. P., Radnor, Z., \& Nasi, G. (2013). A New Theory for Public Service Management? Toward a (Public) Service-Dominant Approach. American Review of Public Administration, 43(2), 135-158. https://doi.org/10.1177/0275074012466935.

Rothwell, W. J. (2015). Practising organization development: Leading transformation and change. Fourth Edition. New Jersey: John Wiley and Son Inc.

Sinambela, L. P., Rochadi, S., Ghazali, R., Muksin, A., Setiabudi, D., Bima, D., \& Syaifudin. (2008). Reformasi Pelayanan Publik Teori, Kebijakan, dan Implementasi. Jakarta: Bumi Aksara.

Sufi, W., \& Herlinda, D. (2017). Penerapan Sistem Aplikasi Pelayanan Kepegawaian (SAPK) Berbasis Online Pada Badan Kepegawaian Daerah Kota Pekanbaru. JURNAL NIARA, Vol. 9, No. 2, 91-100.

Ulfa, \& Sulfiani, A. N. (2018). Inovasi Sistem Informasi Manajemen Adminstrasi Perizinan di Dinas Penanaman Modal dan Pelayanan Terpadu Satu Pintu Kota Palopo. Jurnal Administrasi Negara, Vol 24, No. 2, 127-138. 
86 Jurnal Ilmiah Ilmu Administrasi Publik: Jurnal Pemikiran dan Penelitian Administrasi Publik Volume 9 Number 1, January - June 2019. Page 77-86

Worldwide Governance Indicators. (2018, September 11). Retrieved November 12, 2018, from https://info.worldbank.org 